chiếm tỷ lệ CMSĐ cao hơn số sản phụ có thai nhi trên 3500 gram.

- Thời điểm chảy máu sau đẻ hay gặp nhất 02h chiếm khoảng 95\%.

\section{TÀI LIÊU THAM KHẢO}

1. Phạm Văn Chung. Nghiên cứu về tình hình chảy máu sau đẻ tại bệnh viện phụ sản trung ương trong 2 giai đoan 1998-1999 và 2008-2009. Luân văn tốt nghiệp bác sĩ nội trú, Trường Đại Học Y Hà Nô̂i. 2009.

2. Nguyễn Thị Dung, Nghiên cứu một số nguyên nhân và kết quả xử trí chảy máu sau đẻ tại BV Phụ sản Hà nối trong năm 2014, Luân văn Thạc sĩ Y học, Trường Đại học Y Hà Nội, Hà Nội. 2014.
3. Trân Chân Hà, Nghiên cứu tình hình chảy máu sau đẻ tai viên BVBMTSS trong 5 năm (1996 2000), Luận văn thạc sĩ Y học, Trường Đại học Y Hà Nội, Hà̀ Nội. 2001.

4. Tô Thi Thu Hằng, Nghiên cứu tình hình các bà mẹ lớn tuổi đẻ con so tại viện BV BMTSS từ năm 1996-2000, Luận văn Thiac sỹ Y học, Trường Đại hoc Y Hà Nôi, Hà Nô̂i. 2001

5. Hứa Thanh Sơn, Bùi Sương, Lưu Quốc Khải, "Xử trí tích cức giai đoan 3 cuốc chuyển da tại BV PSHN 1994-1999" 2000.

6. Tổ chức Y tế Thế giới (WHO), WHO recommendations for the prevention and treatment of postpartum haemorrhage, Publications of the World Health Organization Printed in Italy. 2012.

\title{
CHI PHÍ TRỰC TIẾP ĐIỀU TRI UNG THƯ VÚ HER2 DƯƠNG TÍNH TẠI BẾNH VIẾN K NĂM 2020
}

\section{Trần Văn Dũng*, Lưu Hồng Huy*, Nguyễn Đức Tuấn*}

\section{TÓM TẮT}

Mục tiêu nghiên cứu: Để xác định chi phí trực tiếp đîêu trị nội trú của bệnh nhân ung thư vú HER22 dương tính tại Bệnh viện K năm 2020. Đối tượng nghiên cứu: Hồ sơ 80 bệnh án của bệnh nhân được chẩn đoán ung thư vú HER2 dương tính và được điều trị nội trú tại Bênh viện $\mathrm{K}$ năm 2020, được lưu trữ trên phần mềm quản lý của Bệnh viện K. Phương pháp nghiên cứu: Nghiên cứu mô tả cắt ngang. Kêt quả và kết luân: Nghiên cứu cho thấy, đợt điều trị hiện tại, chi phí trực tiếp điêuu trị cho người bệnh ung thư vú HER2 dướng tính là khoảng 20.010.000 VNĐ vớl thấp nhất là 1.034.000 VND và cao nhất là 97.852 .000 VNĐ. Tỷ lệ bảo hiểm y tế chi trả là trên $60 \%$ trong số những người bệnh dùng bảo hiểm. Chi phí điều trị trực tiếp có xu hướng tăng khi giai đoạn bệnh tăng.

Từ khóa: HER2 dương tính, ung thư vú, chi phí điều trị trực tiếp.

\section{SUMMARY}

\section{DIRECT COST OF HER2-POSITIVE BREAST} CANCER TREATMENT AT K HOSPITAL 2020

Objective: To determine the direct cost of inpatient treatment of patients with HER2-positive breast cancer at K Hospital in 2020. Subject: Records of 80 patients' medical records, who were diagnosed with HER2 + breast cancer and treated at K Hospital in 2020. Data is stored on the management software of K Hospital. Method: A cross-sectional descriptive study. Result and conclusion: The study showed that the direct cost of treating HER2-positive breast

*Bênh viện $K$

Chịu trách nhiệm chính: Trần Văn Dũng

Email: dungtranvk1011@gmail.com

Ngày nhận bài: 14.9.2021

Ngày phản biên khoa hoc: 12.11.2021

Ngày duyệt bài: 19.11.2021 cancer patients in one session was 20.010.000 VND with the lowest of 1.034.000 VND and the highest cost of 97.852.000 VNĐ. Health insurance coverage is over $60 \%$ of total direct costs among insured patients. Direct treatment costs tend to increase as the stage of the disease increases.

Keywords: HER2-positive breast cancer, direct treatment costs.

\section{I. ĐẶT VẤN ĐỀ}

Ung thư vú là căn bênh ung thư phổ biến nhất của phụ nữ trên thế giới cũng như ở Việt Nam, đồng thời là nguyên nhân hàng đầu gây tử vong do ung thư ở nữ giới. Theo Cơ quan nghiên cứu ung thư quốc tế (IARC) ước tính năm 2020 có hơn 2 triệu ca ung thư vú mắc mới và gần 700.000 ca tử vong do ung thư vú trên toàn thế giới. Tại Việt Nam năm 2020 báo cáo gần đây cho thây có 182.563 ca mắc mới ung thư', trong đó tì lệ mắc mới ung thư vú đứng thứ ba với 21.555 ca, chiếm tỷ lệ $11,8 \%$. Tỉ lệ tử vong của ung thư vú ở nước ta đứng thứ ba với $9.345 \mathrm{ca}$, chiếm tỷ lệ $7,6 \%$ số ca tử vong do các loại ung thư [1].

Ung thư vú có HER2 dương tính (thụ thể yễu tố phát triển biểu mô 2- Human Epidermal growth factor Receptor 2) chiếm khoảng 15-20\% trong các loại ung thư vú, được xem là một trong những nhóm bệnh có tiên lượng xấu nhất và được xếp vào nhóm nguy cớ cao. Trong những năm gần đây, nhiêu phác đồ như trastuzumab cùng với paclitaxel hoăc docetaxel đã được áp dụng trong điều trị ung thư vú HER2 dương tính và mang lại nhiều kết quả tích cực về thời gian sống thêm của bệnh nhân. Tuy nhiên, tình trạng bệnh ung thư vú HER2 dương tính vẫn 
có tiên lượng xấu hơn và diễn biến bệnh thường nhanh hơn so với các loại ung thư vú khác [2].

Chi phí điều trị ung thư vú có tác động đáng kể đến kinh tế xã hội tại tất cả các nước, đặc biệt các nước đang phát triển như Việt Nam. Tại Mỹ, chi phí y tế liên quan đến ung thư là trên 124,6 tỷ đô la Mỹ mỗi năm, trong đó chi phí điều trị ung thư vú chiếm mức cao nhất,16,5 tỷ đô la Mỹ. Trong khi đó tại Anh, một nghiên cứu cho thấy chi phí trung bình ước tính cho bệnh nhân ung thư vú là trên 7000 bảng Anh và tổng gánh nặng kinh tế của ung thư vú cho toàn nước Anh là trên 243 triệu bảng Anh [3]. Tại Hàn Quốc, chi phí trung bình cho một chu kỳ điều trị ung thư vú kéo dài 4 năm là khoảng 40.000 đô la Mỹ. Tại Việt Nam, nghiên cứu của Nguyễn Thị Thu Thủy và cộng sự (2014) đã chỉ ra rằng gánh nặng kinh tế của bệnh ung thư vú tại Việt Nam là 3.477,2 tỷ VNĐ, trong đó gánh nặng kinh tế dành cho thuốc chiếm đa số $(88,7 \%)$ và gánh nặng kinh tế cho giai đoạn III của bệnh chiếm tỷ lệ cao nhất $(60,4 \%)[4]$.

Phân tích chi phí là một trong những công cụ đánh giá kinh tế y tế và cung cấp thông tin hữu ích nhằm lập kế hoạch cho các can thiệp trong dự phòng và điều trị người bệnh [5]. Đây là quá trình thu nhập những thông tin về chi phí của một chương trình, hoạt động và phân tích các thồng tin đó một cách có hệ thống. Nghiên cứu về phân tích chi phí cho phép ước tính toàn bộ các chi phí phải bỏ ra do bệnh tật hay tình trạng nào đó bao gồm chi phí trực tiếp và chi phí gián tiếp. Nghiên cứu chi phí bệnh tật là kỹ thuật kinh tế đầu tiên được áp dụng trong lĩnh vực y tế. Mục đích cơ bản của nghiên cứu chi phí bệnh tật nhằm để xác định các khoản, xác định chi phí mỗi khoản và tổng chi phí cho vấn đề sức khỏe đó. Phân tích này được sử dụng để nhấn mạnh và so sánh mức độ nặng nhẹ của các vấn đề sức khỏe khác nhau nằm trong bối cảnh quốc gia và các nước [6].

Cho đến nay chưa có nhiều nghiên cứu về chi phí trực tiếp điều trị bệnh ung thư, đặc biệt là bệnh ung thư vú HER2 dương tính. Vì vậy, chúng tôi tiến hành nghiên cứu phân tích chi phí trực tiếp điều trị ung thư vú HER2 dương tính tại Bệnh viện $\mathrm{K}$ năm 2020 để cung cấp thông tin về chi phí trực tiếp điều trị của bệnh nhân ung thư vú HER2 dương tính.

II. ĐỐI TƯợNG VÀ PHƯƠNG PHÁP NGHIÊN CứU
Thiết kế nghiên cứu: Nghiên cứu mô tả cắt
ngang.
Đôi tượng nghiên cứu: Hồ sơ bệnh án của bệnh nhân được chẩn đoán ung thư vú HER2 dương tính và được điều trị nội trú tại Bệnh viện $\mathrm{K}$ năm 2020 và được lưu trữ trên phẩn mềm quản lý của Bệnh viện K.

Thời gian và địa điểm nghiên cứu: Từ tháng 03/2021 đến tháng 11/2021 tại Bệnh viện K.

Cỡ mẫu: Áp dụng công thức tính cỡ mẫu ước lượng giá trị trung bình. Trong đó, $\mathrm{N}$ : Là số bênh án của nguời bệnh cần điều tra, Z: Hệ số tin cậy (Với độ tin cậy $95 \%$ thì giá trị của $Z=1,96$ ), o: Giá trị ước lượng của độ lệch chuẩn của đặc tính nghiên cứu trong quần thể, $\varepsilon$ : Độ chính xác tương đối, $\mu$ : Giá trị trung bình của đặc tính nghiên cứu trong quần thể.

Tại Việt Nam, các nghiên cứu cụ thể về người bệnh ung thư vú HER2 dương tính còn hạn chế. Do vậy, sử dụng số liệu của nghiên cứu chi phí trực tiếp điều trị bệnh ung thư vú nói chung với $\mu=173$ triệu đồng và $\sigma=143$ triệu đồng; lây $\varepsilon$ $=0,2$ thì số lượng người bệnh ung thư cần thiết để triển khai là 66 người bệnh. Bên cạnh đó, cõ mẫu của nghiên cứu chi phí điều trị trực tiếp ung thư vú năm 2019 tại Bệ̂nh viện K là 87 người bệnh [7]. Do vậy, cỡ mẫu nghiển cứu này là 80 .

Phương pháp thu thập số liệu: Tiến hành hồi cứu hồ sơ bệnh án và truy xuất thông tin trên phần mềm quản lý dữ liệu của Bệnh viện trên những bệnh nhân phù hợp với tiêu chuẩn lựa chọn. Sử dụng phiếu thu thập số liệu đã được thiết kế sắn ghi chép các thông tin về bênh nhẩn và thông tin về các đợt điều trị của bệnh nhân từ hồ sơ bệnh án của bệnh nhân lưu trữ tại Bệnh viện $\mathrm{K}$.

Quản lý và phân tích số liệu: Số liệu được nhập bằng phần mềm excel 2010, phần mềm Epidata 3.1 và được xử lý bằng phần mềm SPSS22. Khung phân tích chi phí và chi phí của các dịch vụ được tiến hành trong năm 2020. Trong đó, tổng chi trực tiếp cho y tế $=$ chi cho chẩn đoán + chi cho điêuu trị + chi phí ngày-giường. Trong đó: Chi cho chẩn đoán: chi cho các xét nghiệm cận lâm sàng. Chi cho điều trị bao gồm: Chi phí cho phẫu thuật, Chi phí cho hóa chất, Chi phí cho xạ trị. Thống kê mô tả bao gồm trung bình, trung vị, độ lệch chuẩn cho biến định lượng.

\section{KẾT QUẢ NGHIÊN CỨU}

1. Thông tin chung của đối tượng
nghiên cứu.
Bảng 1. Thông tin chung của người bệnh
tham gia nghiên cứu
\begin{tabular}{|c|c|c|}
\hline \multicolumn{3}{|c|}{ Đặc điếm } \\
\hline \multicolumn{3}{|c|}{ Nhóm tuối } \\
\hline Dướ 30 & 1 & 1,2 \\
\hline $30-39$ & 9 & 11,2 \\
\hline
\end{tabular}


VIETNAM MEDICAL JOURNAL N²2 - DECEMBER - 2021

\begin{tabular}{|c|c|c|}
\hline $40-49$ & 19 & 23,8 \\
\hline $50-59$ & 28 & 35 \\
\hline $60-69$ & 17 & 21,3 \\
\hline Trên 70 & 6 & 7,5 \\
\hline \multicolumn{3}{|c|}{ Tình trang công viêc hiện tại } \\
\hline Thất nghiêp/Chưa có việc làm & 12 & 15,0 \\
\hline Hưu trí & 18 & 22,5 \\
\hline Đang có việc làm & 50 & 62,5 \\
\hline \multicolumn{3}{|l|}{ Trình độ văn hóa } \\
\hline Chưa hết tiếu học & 5 & 6,2 \\
\hline Tiếu học & 11 & 13,8 \\
\hline Trung học cơ sở & 13 & 16,2 \\
\hline Trung học phố thông & 28 & 35,0 \\
\hline Cao đằng/đại học và trên & 23 & 28,8 \\
\hline \multicolumn{3}{|l|}{ Bảo hiếm y tế } \\
\hline Không & 5 & 6,2 \\
\hline Có & 75 & 93,8 \\
\hline
\end{tabular}

\begin{tabular}{|c|c|c|}
\hline \multicolumn{3}{|c|}{ Giai đoạn bệnh } \\
\hline Giai đoạn I & 9 & 11,2 \\
\hline Giai đoạn II & 44 & 55,0 \\
\hline Giai đoạn III & 21 & 26,3 \\
\hline Giai đoạn IV & 6 & 7,5 \\
\hline
\end{tabular}

Bảng 1 mô tả thông tin chung của 80 người bệnh ung thư vú HER2 dương tính, trong đó phân bố tỷ lệ cao nhất tại các nhóm tuổi từ 50 $59(35 \%)$, 40-49 tuổi $(23,8 \%)$ và 60-69 tuổi (21,3\%). Về công việc hiện tai, tỷ lệ đang có việc làm, hưu trí và chưa có việc làm lân lượt là $62,5 \%, 22,5 \%$ và $15 \%$. Tỷ lệ người bệnh có trình độ từ trung học phổ thông trở lên là 63,8\%. Có 93,8\% người bệnh có tham gia bảo hiểm y tế và người bệnh ở giai đoạn II (55\%) và giai đoạn III $(26,3 \%)$ chiếm tỷ lệ cao nhất.

2. Chi phí điêu trị trực tiếp ung thư vú HER2 dương tính

Bảng 2. Cấu phần chi phí trực tiếp cho y tế

\begin{tabular}{|c|c|c|c|c|c|}
\hline Hạng mục chi phí & Mean & SD & Min & Max & Median \\
\hline Giường bệnh & 2.681 & 12.777 & 251 & 81.441 & 635 \\
\hline Cận lâm sàng (XN, CĐHA) & 4.206 & 2.859 & 413 & 12.416 & 3.778 \\
\hline Thuốc & 7.892 & 9.058 & 0 & 33.234 & 3.115 \\
\hline Thủ thuật, phâuu thuật & 3.954 & 4.693 & 0 & 20.573 & 3.157 \\
\hline Vật tư' tiêu hao & 222 & 4.693 & 0 & 322 & 141 \\
\hline Tống & $\mathbf{2 0 . 0 1 0}$ & $\mathbf{2 3 . 4 3 3}$ & $\mathbf{1 . 0 3 4}$ & $\mathbf{9 7 . 8 5 2}$ & $\mathbf{1 0 . 6 4 1}$ \\
\hline
\end{tabular}

Trong cấu phần chi phí trực tiếp của người bệnh, chi phí trung bình về thuốc (khoảng 7.892 .000 VNĐ) lớn nhất, tiếp sau đó là chi phí cận lâm sàng (khoảng 4.206.000 VNĐ), thủ thuật, phẫu thuật (khoảng 3.954.000 VNĐ) và giường bệnh (khoảng 2.681.000 VNĐ). Trung bình chi phí vật tư tiêu hao chỉ khoảng 222.000 VNĐ.

Bảng 3. Chi phí trung bình một điều trị UTV HER2 dương tính theo sử dụng bảo hiếm $y$ tế Đơn vi tính: 1.000 VND

\begin{tabular}{|c|c|c|c|c|c|c|}
\hline Sử dụng BHYT & Chi phí điều trị & Mean & SD & Min & Max & Median \\
\hline Không & Tự chi trả & 14.090 & 636 & 1.039 & 1.940 & 14.090 \\
\hline \multirow{3}{*}{ Có } & Tự chi trả & 8.361 & 11.026 & 282 & 53.738 & 4.002 \\
\cline { 2 - 7 } & Bảo hiếm y tế & 12.623 & 15.492 & 221.645 & 85.022 & 6.681 \\
\cline { 2 - 7 } & Tống & 20.984 & 23.649 & 1.034 & 97.852 & 11.344 \\
\hline \multicolumn{2}{|r|}{ Tống chung } & 20.010 & 23.433 & 1.034 & 97.852 & 10.641 \\
\hline
\end{tabular}

Theo bảng 3 , trung bình chi phí trực tiếp điều tri của người bênh ung thư vú HER2 dương tính theo một đợt điều trị và không sử dụng bảo hiểm y tế là khoảng 14.090.000 VNĐ. Trong khi đó, đối với người bệnh có bảo hiểm y tế, chi phí người bệnh tự chi trả là khoảng 8.361 .000 VNĐ và bảo hiểm y tế chi trả là khoảng 12.623.000 VNĐ cho một đợt điều trị.

Bảng 4. Chi phí điều trị trực tiếp của đối tượng nghiên cứu theo giai đoạn bệnh

\begin{tabular}{|c|c|c|c|c|c|}
\hline \multicolumn{6}{|c|}{ Dơn vi tính: $1.000 \mathrm{VNE}$} \\
\hline Hạng mục & Trung bình & SD & Min & Max & Median \\
\hline Giai đoạn I & 1.039 & 1.347 & 923 & 1.739 & 1.368 \\
\hline Giai đoạn II & 12.899 & 11.103 & 1.940 & 24.141 & 12.616 \\
\hline Giai đoạn III & 23.267 & 24.998 & 1.034 .573 & 97.852 & 15.154 \\
\hline Giai đoạn IV & 17.770 & 23.585 & 2.677 & 93.418 & 8.797 \\
\hline
\end{tabular}

Theo kết quả của bảng 4 , chi phí trực tiếp trung bình một đợt điều trị người bệnh cao nhất ở giai đoạn III (khoảng 23.267.000 VNĐ), tiếp sau đó là giai đoạn IV (khoảng 17.770.000 VNĐ)

và giai đoạn II (khoảng 12.899.000 VNĐ). Trong khi đó, chi phí trực tiếp trung bình một đợt điều trị người bệnh cao nhất ở giai đoạn I chỉ là khoảng 1.039.000 VNĐ. 


\section{BÀN LUÂN}

1. Đăc điểm của người bênh ung thư vú HER2 dương tính điều trị tại Bệnh viện $K$ năm 2020. Tỷ lệ người bệnh có độ tuổi trển 45 tại nghiên cứu này là $67,5 \%$, chiếm tỷ lệ lớn. Tuy nhiên, có thể thấy tỳ lệ người bệnh có độ tuổi từ 30 đến 45 tuổi chiếm tới $28,8 \%$. Ung thư vú nói chung và ung thư vú HER2 dương tính nói riêng có xu hướng trẻ hoá. Tuy nhiên, tỷ lệ vẫn tập trung chủ yếu ở giai đoạn trung niên. Điều này cũng phù hợp với nghiên cứu White và cộng sự (2014) đã chỉ ra mối liên hệ giữa tuổi và nguy cơ mắc ung thư, trong đó tỷ lệ mắc ung thư tăng theo tuổi và tăng nhanh từ độ tuổi trung niên. Tỷ lệ người bệnh ở giai đoạn I \& giai đoạn II chiếm tới $66,2 \%$ và giai đoạn IV chiếm $7,5 \%$. Điều này cũng phù hợp với nghiên cứu của Nguyễn Mai Lan (2021) [8] với tỷ lệ người bệnh ở các giai đoạn bênh. Với tỷ lệ người bệnh ở giai đoạn sớm, điểu này có thể cho thãy rằng tỷ lệ khám, sàng lọc phát hiện sớm đã có những hiệu quả.

2. Chi phí điêuu trị trực tiếp ung thư vú HER2 dương tính tại Bệnh viện $K$ năm 2020. Trong các cấu phần chi phí trực tiếp điều trị người bệnh ung thư vú HER2 dương tính, chi phí thuốc (7.892.000 VNĐ) và cận lâm sàng (4.206.000 VND) là cao nhất. Theo từng đợt điều trị, trung bình chi phí trực tiếp điều trị ung thư vú HER2 dương tính là khoảng 20.010.000 VND, với chi phí thấp nhất là khoảng 1.034.000 VNĐ và chi phí cao nhất là 97.852.000 VNĐ. Khi đề cập đến sự tham gia của bảo hiểm y tế trong nghiên cứu này, bảo hiểm y tế đã chi trả trung bình trên $60 \%$ (khoảng 12.623.000 VND) tổng số chi phí trực tiếp điều trị của người bệnh ung thư vú HER2 dương tính tính theo môt đợt điều trị. Có thể thây rằng tham gia bảo hiểm y tế góp phần giảm gánh nặng chi trả điều trị cho người bệnh, đặc biệt người bênhh ung thư.

Theo giai đoạn bệnh, chi phí điều trị trực tiếp có xu hướng tăng theo mức tăng của giai đoạn bệnh. Điều này được lý giải khi người bệnh ở các giai đoạn bệnh muộn hơn (giai đoạn III và IV), cần phải chi phí nhiều hơn cho các can thiệp điều trị (phẫu thuật, hoá chất, xạ trị và thuốc điều trị) phức tạp hơn. Điều này cũng phù hợp với nghiên cứu của Nguyễn Thi Thu Thuỷ và cộng sự (2014) về gánh năng chi phí điều trị ung thư vú tăng khi giai đoạn bệnh tăng từ giai đoạn I đến giai đoạn IV [9]. Có thể thấy rằng việc phát hiện và điều trị sớm ung thư vú góp phần giúp họ giảm chi phí điều trị cho người bệnh.

Hạn chế của nghiên cứu: Nghiên cứu này triển khai với quy mô cõ mẫu chưa lớn, chỉ mô tả chi phí điều trị trực tiếp và chỉ sử dụng số liệu trên hồ sơ bệnh án. Tuy nhiên, các kết quả của nghiên cứu đã chỉ ra những điểm nổi bật trong chi phí trực tiếp điều trị, chi trả của bảo hiểm y tế và chi trả của người bệnh theo từng giai đoạn bệnh. Do vậy, kết quả này sẽ là tiền đề và gợi ý quan trọng để tiến hành một nghiên cứu có quy mô lớn hơn và đánh giá chi phí tổng thể của người bệnh ung thư vú (bao gồm cả chi phí trực tiếp và chi phí gián tiếp) nhằm mô tả cũng như đánh giá được toàn diện về chi phí điều trị ung thư vú HER2 dương tính.

\section{KẾT LUÂ̂N}

Nghiên cứu cho thấy, theo từng đợt điều trị, trung bình chi phí trực tiếp điều trị ung thư vú HER2 dương tính là khoảng 20.010.000 VNĐ, với chi phí thấp nhất là khoảng 1.034.000 VNĐ và chi phí cao nhất là 97.852.000 VNĐ. Theo cấu phần chi phí trực tiếp điều trị theo từng đợt, chi phí thuốc (7.892.000 VNĐ) và cận lâm sàng (4.206.000 VNĐ) là cao nhất. Bảo hiểm y tế đã chi trả trung bình trên $60 \%$ (12.623.000 VNĐ) tổng số chi phí trực tiếp điều trị cho người bệnh theo một đợt điêu trị. Theo một đợt điêu trị, chi phí điều trị trực tiếp có xu hướng tăng khi giai đoạn bệnh tăng, trong đó người bệnh ở giai đoạn III (23.267.000 VNĐ) có chi phí cao nhất.

\section{TÀI LIÊU THAM KHẢO}

1. Globocan, 2021, truy cập ngày 01/03/2021,

"https://gco.iarc.fr/today/data/factsheets/populations/ 704-viet-nam-fact-sheets.pdf".

2. Loibl, S. and Gianni, L., 2017. HER2-positive breast cancer. The Lancet, 389(10087), trang 2415-2429.

3. Dolan, P., Torgerson, D. J., \& Wolstenholme, J. (1999). Costs of breast cancer treatment in the United Kingdom. The breast, 8(4), trang 205-207.

4. Nguyến, T. T. T., \& Nguyến, V. H. (2014). Đánh giá gánh năng kinh tế của ung thư vú tại Việt Nam, Kỷ yếu hội nghị khoa học công nghệ tuổi trẻ các Trướng Đại học \& Cao đẳng 2014, trang 838-843.

5. Mahar, A.L., N.G. Coburn, and A.P. Johnson, 2014, A population-based study of the resource utilization and costs of managing resectable non-small cell lung cancer. Lung Cancer, 86(2): trang 281-7.

6. Corral, J., Espinàs, J.A., Cots, F., Pareja, L., Solà, J., Font, R. and Borràs, J.M., 2015. Estimation of lung cancer diagnosis and treatment costs based on a patient-level analysis in Catalonia (Spain). BMC health services research, 15(1), trang.1-10.

7. Nguyển Quỳnh Anh và Nguyễn Thu Hà, 2021 Chi phí trực tiếp điều trị ung thư vú tại Việt Nam năm 2019, Tapp chí Y học Việt nam, 502 (2).

8. Nguyễn Thị Mai, Lan, 2021. Nghiên cứu tỷ lệ mắc mới ung thư vú ở phụ nữ Hâ Nội giai đoạn 2014-2016 (Doctoral dissertation).

9. Nguyễn Thị Thu Thuỷ và Nguyễn Văn Hà, 2014. Đánh giá gánh nặng kinh tế của ung thư vú tại Việt Nam. 